\title{
PERFORMING THE PEOPLE
}

\author{
Benjamin Lee
}

\section{Introduction}

The invention in the New World of national communities imagined to be independent, equal and comparable to those of Europe was at its time "felt to be something absolutely unprecedented, yet at the same time, once in existence, absolutely reasonable (Anderson 1983: 192)." The inaugural event was the American Revolution, with the Declaration of Independence announcing the formation of a sovereign people and the Constitution declaring "we, the people" to be the subject/agent of an open ended, self-constituting political process. The American idea of a nation embodying and representing a sovereign people was something both startling and new, and then immediately imitated in the constitutions of other nations.

Although the invention of "the people" was a long, historical process, its roots lie in the new forms of subjectivity developing in the public spheres of Europe and its colonies during the eighteenth century. In philosophy, the "inward turn" (Taylor 1990) begun by Augustine takes the self-reflexive examination of consciousness as the starting point for both morality and epistemology. Descartes' cogito and its dico variant make the self-evident truths produced by self-reflexiveness the core of a radically new role for individual consciousness: That of the ground for morality and epistemology, not merely the tool for discovering some other ultimate authority, such as God in Augustine's account. Locke rejects Descartes' appeal to innate ideas; he not only further objectifies and instrumentalizes subjectivity, but also posits a model of how society can be created out of the mutual consent of individuals who see themselves and society in the light of this new model of consciousness and agency. Implicit in the Lockean move is a further removal of God as society's performative source and a relocation of that performativity in the social contract.

These new forms of philosophical subjectivity were developing in what Jurgen Habermas has termed the "bourgeois public sphere"; they provided a political ideology for the emerging bourgeois class in its struggles with the absolutist state. Yet as Habermas himself points out, this public sphere also nurtured the development of new forms of "expressive" subjectivity which were most clearly realized in the development of fictional narration. The juncture between philosophy and literature will also provide the "transportable" forms necessary for Anderson's imagined communities of nationalism. The crucial moment is when a new structuring consciousness emerges through the development of a print capitalism mediated by an institutionally structured, self-reflexive appropriation of the meta-linguistic potentials of narration. Narration is constituted by a semiotic reflexivity of the event of narration and the narrated event, whose coordination reveals the locus of a new 
type of subjectivity, that of the narrator. The changes in novelistic form and narration during the rise of the bourgeois public sphere parallel those in philosophy. The authority of omniscient narration interacts with a new form of narration which was especially popular around the time of the American Revolution, that of the epistolary novel; the epistolary novel created a tone of narratorial intimacy and reader solidarity among an extended, print mediated audience which contrasted sharply with the "objectivity" of omniscient narration.

Earlier ideologies of printing constructed print as the extension of face-toface communication. In the bourgeois public sphere, people began to see printing as foregrounding writing's potential for unlimited dissemination, thereby creating a print-mediated difference between public discourse and the world of letters that characterizes private correspondence. As Michael Warner has argued (Warner 1990), the critical transformation is when communication is seen not as face-to-face relation between people but rather as mediated by a potentially limitless discourse. It is in this space that narrated texts insert themselves and become the semiotic base for new forms of subjectivity.

This space is at least doubly metalinguistic. First, philosophical and narrated texts are formally metalinguistic in their use of reported speech, double voicing, indirect discourse, and free indirect style to construct the relation between narrator and narrated material or the philosophical self-reflexive examination of consciousness. Second, the discussion of such texts is also metalinguistic, and accounts such as those of Habermas, Taylor, Anderson, and Warner could be interpreted as showing how these emergent forms of consciousness contribute to the development of nationalism, civil society, and the modern nation-state. Concepts such as public opinion, the voice of the people, and popular sovereignty are metalinguistic objectifications of the intersection of narrated and philosophical discourses and the public spaces they create and mediate.

\section{The founding problem}

It is now difficult to see the founding documents of the United States as ushering in a new social form of modernity. Yet as both Anderson and Hannah Arendt (1963) point out, they announce the creation of a political subjectivity that breaks with traditional forms of legitimation. In neither document are there references to the antiquity of the American people or a continuity of culture and custom that binds them; instead, there was "a profound feeling that a radical break with the past was occurring - a 'blasting open of the continuum of history' (Anderson 1983: 193)", the idea of which would spread and be emblazoned in the French Revolutionary calendar's marking of a new world era starting with the Year One of the new French Republic.

The modern concept of revolution, inextricably bound up with the notion that the course of history suddenly begins anew, that an entirely new story, a story never known or told before, is about to unfold, was unknown prior to the two great revolutions at the end of the eighteenth century. Before they were engaged in what then turned out to be a revolution, none of the actors had the slightest premonition of what the plot of the new drama was going to be. However, once the revolutions had begun to run their course, and long before those who were involved in them could know whether their enterprise would end in victory 
or disaster, the novelty of the story and innermost meaning of its plot became manifest to actors and spectators alike. As to the plot, it was unmistakably the emergence of freedom....(Arendt 1963: 28)

Revolution combined the ideas of a unique beginning and freedom while also creating a new historical subject and agent. The revolutionary project of "inventing the people" produces a new form of make-believe which "then takes command and reshapes reality (Morgan 1988: 14)" even as it attempts to establish a unique history for each new nation. Yet ultimately, revolutions simply replace one form of makebelieve with another.

At the time when England's American colonies were founded, the fictions that sustained government - and liberty - were almost the reverse of those we accept today. Englishmen of the sixteenth and seventeenth century affirmed that men were created unequal and that they owed obedience to government because the Creator had endowed their king with his own sacred authority. These propositions too were fictional, requiring suspension of disbelief, defying demonstration as much as those that took their place. How then did the one give way to the other? How did the divine right of kings give way to the sovereignty of the people? How did the new fictions both sustain government by the few and restrain the few for the benefit of the many? In other words, how did the exercise and authentication of power in the Anglo-American world as we know it come into being? (Morgan 1988: 15)

The battle to create a sovereign people contains within it the overthrow of an older order of legitimacy, that based upon the divine right of kings. Yet to overthrow this source of legitimacy was to call into question that which had always been assumed: governments were legitimated by higher laws. If religion could not provide the source of legitimacy, what could? Even more specifically, what legitimates the constitution of a modern nation when traditional sources of authority have become effaced by a rising secularism? Arendt describes the situation as a vicious circle:

...those who get together to constitute a new government are themselves unconstitutional, that is, they have no authority to do what they have set out to achieve. The vicious circle in legislating is present not in ordinary lawmaking, but in laying down the fundamental law, the law of the land or the consticution which, from then on, is supposed to incarnate the 'higher law' from which all laws ultimately derive their authority. And with this problem, which appeared as the urgent need for some absolute, the men of the American Revolution found themselves no less confronted than their colleagues in France. The trouble was - to quote Rousseau once more - that to put the law above man and thus to establish the validity of man-made laws, il faudrait des dieux, 'one actually would need gods'. (Arendt 1963: 184)

\section{The American solution}

When the colonists first came to the United States, they came as Englishmen. There was no crisis of legitimacy or issue of sovereignty, no vicious circle to be undone. The Mayflower Compact was drawn up in Britain before the colonists left for the New World; they left under the jurisdiction of the Virginia Company and signed the Compact aboard the Mayflower before it ever landed. The Compact combines a performative moment of mutual agreement, sanctioned by 
God, with a constitutional one:

we solemnly and mutually in the Presence of God and one another, covenant and combine ourselves together into a civil Body Politick...; and by virtue hereof enact, constitute, and frame, such just and equal Laws, Ordinances; Acts, Constitutions, and Offices, from time to time, as shall be thought most meet and convenient for the general Good of the Colony; unto which we promise all due Submission and Obedience.... (quoted in Arendt 1963: 173)

Within one hundred and fifty years, the different threads woven into the Compact would begin to unravel around the problem of representation. Nearly all of the great debates of the period, beginning with the imperial controversy in the 1760s and ending with the clash over the new Federal Constitution in the 1780 s, were ultimately grounded in the problem of representation. Indeed, if representation is defined as the means by which the people participate in government, fulfillment of a proper representation became the goal and measure of the Revolution itself, "the whole subject of the present controversy" as Thomas Jefferson put it in 1775. (Wood 1969: 1)

The American Revolution would replace the monarchy as the source of authority with the vox populi. The king issues commands in God's name; the people would replace him as the performative source of law. Unlike the French Revolution, the American solution would be to separate the sources of power and law by a printed textual mediation. The Constitution would be the source for law; the people would be the source of legitimate power. The distribution of a printed Constitution to be ratified by state legislatures would make possible a new form of social mediation which would then be the source for an abstract notion of the people which would transcend any particular locale, yet be immanent in all the citizenry. As Michael Warner puts it.

..our society's representational policy rests on a recognition of the abstract and definitionally nonempirical character of the people. It is the invention of the written constitution, itself now the original and literal embodiment of the people, that ensures that the people will henceforward be nonempirical by definition. (Warner 1990: 103)

\subsection{Hannah Arendt}

The creativity and unprecedented nature of the American solution to the vicious circle paradox has been forcefully argued for by Hannah Arendt in her book On Revolution, and extended by Bonnie Honig in her Derridean update of Arendt and in Michael Warner's Habermas inspired work on the Republican public sphere. Arendt sees this breakthrough in the articulation of a new model of political authority which relies upon consensual agreement rather than any appeal to transcendental authority. Honig points out that Arendt's conception privileges a performative interpretation of modern political authority which, when augmented with some points from Derrida's analysis of the Declaration of Independence, links problems of political power and authority with the performative and constative nature of speech acts. Warner's work adds a new dimension by showing how print mediation contributes to the process of the political legitimation of the Constitution.

Arendt felt that "the colonization of North America and the republican 
government of the United States constitute perhaps the greatest, certainly the boldest, enterprises of European mankind (Arendt 1963: 55) because they founded "an entirely new body politic" which "liberated the power of covenant and constitution-making (ibid, p 168)"; the American colonists discover a new way of "world-making" based not upon some Lockean social contract, but rather what Arendt calls a "mutual contract" (ibid, 169). In Locke's account of the founding of political authority, there are really two social contracts. The first is concluded between individuals and moves them from the state of nature to the state of society. The second is between these social persons and their ruler and legitimates his authority. Since both contracts are fictions, Arendt focuses on the first type of contract in which "each individual person who outside the constituted political realm remains impotent" mutually consents to the creation of a new form of social power from which they all can benefit. This form of "mutual consent" which creates and enhances power while binding it via an egalitarian and reciprocal contract contrast sharply with the contract to create a sovereign in which individuals "resign" their power in their consent to have someone rule them. The two forms of contract distribute power and responsibility differently. The power gained by the individual in the former is in direct proportion to the power he gives over to the ruler in the latter. In mutual consent, people lose their isolation in order to cooperate with one another; in the creation of a sovereign ruler, they protect and safeguard their isolation.

In other words, the mutual contract where power is constituted by means of promises contains in nuce both the republican principle, according to which power resides in the people, and where a 'mutual subjection' makes of rulership an absurdity- 'if the people be governor, who shall be governed?' - and the federal principle, the principle of 'a Commonwealth for increase' (As Harrington called his utopian Oceana), according to which constituted political bodies can combine and enter into lasting alliances without losing their identity. (Arendt 1963: 171)

In an obvious reference to the French Revolution, Arendt points out the totalitarian implications of the 'authority' contract.

It is equally obvious that the social contract which demands the resignation of power to the government and the consent to its rule contains in nuce both the principle of absolute rulership, of an absolute monopoly of power to overawe them all (Hobbes) (which, incidentally, is liable to be construed in the image of divine power, since only God is omnipotent), and the national principle according to which there must be one representative of the nation as a whole, and where the government is understood to incorporate the will of all nationals. (Arendt idem)

Arendt sees the American struggle for independence as the first modern revolution which begins to articulate the implications of a politics of mutual consent. Starting with the Mayflower Compact and running through the Declaration of Independence and the Constitution, "promises and covenants" create and maintain power. In the Mayflower Compact and the Declaration of Independence, these agreements still appeal to God, laws of nature, and self-evident truths. But the Declaration, in the preamble's "we hold these truths to be self-evident", joins this appeal with the mutual subjectivity and agency of a "we" which the Constitution will 
enshrine as the source of its legitimacy as "we the people". For as Arendt points out, the self evident truths "that all men are created equal" and "are endowed by their Creator with certain unalienable Rights" were not of the same order as what were usually considered to be self-evident truths, such as those of mathematics.

Jefferson's famous words, "we hold these truths to be self-evident', combine in a historically unique manner the basis of agreement between those who have embarked upon revolution, an agreement necessarily relative because related to those who enter it, with an absolute, namely with a truth that needs no agreement since, because of its self-evidence, it compels without argumentative demonstration or political persuasion. (Arendt 1963: 192)

In Arendt's opinion, the Constitution is the "true culmination of this revolutionary process". The Declaration of Independence announces and the American Revolution brings about a liberation; the Constitution creates a foundation for a new form of power that enhances freedom - "there is nothing more futile than rebellion and liberation unless they are followed by the constitution of the newly won freedom (Arendt 1963: 142)." The Declaration provides the source of authority from which the Constitution derives its legitimacy; it creates the 'we' that the Constitution presupposes. The Declaration and the Constitution are the founding documents in a process in which men "mutually bound themseives into an enterprise for which no other bond existed, and thus made a new beginning in the very midst of the history of Western mankind (Arendt 1963: 194)."

\subsection{Deconstructing foundations}

Arendt published On Revolution in 1963 during the heyday of French structuralism; three years later Jacques Derrida would introduce deconstructionism to the United States at a famous conference at Johns Hopkins University. At first glance, there would seem to be little relationship between Arendt's political philosophy and deconstructionism, but in a conference celebrating the bicentenary of the Declaration of Independence, Derrida presented an analysis of the Declaration which locates in it the very vicious circle of foundation and legitimation that Arendt says is at the heart of modern politics. The crucial question Derrida raises is "who signs, and with what so-called proper name, the declarative act which founds an institution? (Derrida 1986: 8, italics in original)." The problem is that

The "we" of the declaration speaks "in the name of the people."

But this people does not exist. They do not exist as an entity, it does not exist, before this declaration, not as such. If it gives birth to itself, as free and independent subject, as possible signer, this can hold only in the act of the signature. The signature invents the signer. This signer can only authorize him or herself to sign once he or she has come to the end [parvenu au vout], if one can say, of his or her own signature, in a sort of fabulous retroactivity. That first signature authorizes him or her to sign. (Derrida 1986: 10)

Honig interprets Arendt and Derrida as differing in the role of the constative in political legitimation. Arendt sees it as grounding an order of self evident, absolute, and therefore non-reviseable truths which must be overcome if the democratic implications of government by mutual consent are to develop. Derrida sees the constative as a linguistic necessity, inscribed into every performative event 
of legitimation. Honig proposes that one way to overcome their differences is to accept Derrida's claim that all founding moments contain a constative backing, but, pace Arendt, to resist its claim to irresistibility. In the modern era, politics becomes "a practice of deauthorization"; the "genius of Arendt's account is that Derrida's own project of deauthorization - his adoption of a posture of intervention - becomes a part of a practice of authority, not simply an unauthorized assault on the institutions of authority from some outside (Honig 1986: 111)."

The politics of performativity are highlighted in Arendt's construal of how the Declaration of Independence and the Constitution have become authoritative. The founding fathers were faced with "the problem of how to make the Union 'perpetual', of how to bestow legitimacy for a body politic which could not claim the sanction of antiquity" (Arendt 1963: 202); they found such a model in the structure of Roman authority in "which all innovations and changes remain tied back to the foundation which, at the same time, they augment and increase (idem)."

Thus the amendments to the Constitution augment and increase the original foundations of the American Republic; needless to say, the very authority of the American Constitution resides in its inherent capacity to be amended and augmented. (idem)

Honig draws a parallel between Arendt's notion of augmentation and Derrida's notion of survivance by which something is maintained through translation. Translation for Derrida is not a passive act; it necessarily augments the original meaning by placing it within a new context. Translation partakes of the same structure of iterability as citation; in survivance, the translating text preserves the original moment of foundation by augmenting it with another event, speech act, or text.

Under these interpretations of how "foundation, augmentation, and conservation are intimately interrelated (Arendt 1963: 201)", the Constitution becomes the key text because it authorizes its own continuous revision. Every such revision augments it authority, and in so doing it revalidates its author, "we the people", thereby reinscribing the performative act of the Declaration of Independence as its creative presupposition. By a "fabulous retroactivity", the Constitution reaffirms and draws into it as a living part of a textualized narrative of national history, the future subject whose creation the Declaration both announces and brings into being.

\subsection{Performing the performative}

Honig's interpretations of Derrida and Arendt rely on the performative/constative distinction which was first introduced by John Austin in his work on speech acts. Derrida's interest has been long standing, and evoked a quarrel between him and John Searle, a student of Austin's, over the interpretation of Austin's work. Austin wrote his most influential work, How to Do Things with Words, in order to criticize logical positivists who insisted that non-truth functional and non-empirically verifiable uses of language were meaningless. According to logical positivists, truth functional uses of language included statements, descriptions, and assertions. Among these, those which were empirically verifiable and therefore had specifiable truth 
conditions were meaningful; all others were meaningless. Austin called these truth functional constructions "constatives" and contrasted them to "performatives" such as "I promise to do X." The latter does not seem to be a description or assertion but rather, the making of a promise, an enactment. Among the "humdrum verbs in the first person singular present indicative active" performatives stand out because they are neither true or false nor descriptive or reportive, but are "the doing of an action" rather than merely "saying something" (Austin 1962: 5). He then analyzes the uses of performatives to show that they have "felicity" conditions which play a role similar to that which truth conditions have for constatives; instead of being meaningless, performatives require different assessment conditions than constatives.

Austin made explicit performatives a key to his analysis of illocutionary forces and speech acts. He and others have thought by isolating what made them effective, they could generalize the results to other speech acts which were not so explicitly marked, creating a general doctrine of illocutionary forces. However, it now seems more likely that explicit performatives are actually quite unique in their linguistic properties. They are effective because of their position in a system of metalinguistic relationships, as a form of locutionary "citation" functioning within a more generalized iterability which is at the basis of all linguistic functioning. As Benveniste has pointed out, their uniqueness lies in their creative self-reference.

This leads us to recognize in the performative a peculiar quality, that of being self-referential, of referring to a reality that it itself constitutes by the fact that it is actually uttered in conditions that make it an act. As result of this it is both a linguistic manifestation, since it must be spoken, and a real fact, insofar as it is the performing of an act. The act is thus identical with the utterance of the act. The signified is identical to the referent. This is evidenced by the word "hereby." The utterance that takes itself as a referent is indeed selfreferential. (Benveniste 1966: 236)

To the extent that performatives are creatively self-referential, i.e. that they create the act they seem to refer to, they create the maximal contrast between the creativity of linguistic reference and the contextual conditions that need to be presupposed to make such reference effective. The creative indexical properties of performatives bring about the conditions that make them true; their referential and predicational structures seem to classify that created token as an instance of the speech act named by the predicate.

The crucial features of performatives for Honig's analysis is that they require a first person subject, a performative verb in the present, nonprogressive tense and aspect, and that they create what they refer to. Examples are "we...do formally publish and declare" of the closing lines of the Declaration of Independence, and the opening lines of the Constitution, "we the people of the United States...do ordain and establish this constitution for the United States of America." According to Honig, Arendt tries to establish a notion of political authority which derives directly from the pure perfomativity of people promising and making social contracts. Derrida insists that any performative which is effective as a founding instance, requires some form of constative backing which in the Declaration comes in the form of the appeal to God; Arendt views the founding fathers' apeal to God as showing their incompleteness awareness of the breakthrough they were bringing about. 


\subsection{Constitutional subjectivity}

Despite the apparent continuity between the "we" of the Declaration of Independence and the Constitution, it is immediately evident that this relationship is a historically constructed one which links two different subjects. The "People" of the colonies appealed to at the end of the Declaration is not the same "people" which opens the Constitution. The latter was created by James Madison, agreed upon by the Constitutional Convention, and ratified by the state legislatures. It was, as Morgan has put it, an "invention."

But even before the convention met, Madison recognized that it could achieve the objectives he had in mind for it only by appealing to a popular sovereignty not hitherto fully recognized, to the people of the United States as a whole. They alone could be thought to stand superior to the people of any single state. (Morgan 1988: 267)

Although this notion of "the people" would draw upon the peoples of the individual states, it would be "a separate and superior entity" which would give to the "national government an authority that would necessarily impinge on the authority of the state governments (idem)."

Madison's invention was responding to several crises. First, the Continental Congress lacked the legislative authority to get the various states to work effectively together after the threat of war was over. As the Declaration itself stated, its representatives were indirectly elected by the state legislatures. The Congress itself was made up of the elite sectors of colonial society, and, since it lacked a directly elected house of representatives, it could not claim to directly represent the people. The state legislatures could claim to represent their constituencies, but the Congress has no corresponding claim that could "trump" those of the states; it therefore lacked the sovereign powers of a truly national government. By 1787 , Congress' lack of legislative authority had produced a crisis. There were secessionist uprisings in Massachusetts, New Hampshire, and Connecticut. John Marshall, the future chief justice of the Supreme Court, thought unless there was a national government with effective powers, there would be "anarchy first, and civil convulsions afterwards (quoted in Morgan: 267)."

Yet creating a solution that would give some entity both power and legitimacy would require a new conceptualization of representation. Much of the revolutionary rhetoric was a critique of indirect and virtual political representation. During the Stamp Act debates, it was argued not only that the colonies were not properly represented in the Parliament, but it was even suggested that because of the distances involved, they could never be because any representatives would soon lose touch with local issues. With the Declaration of Independence, these issues of representation soon became involved in the vicious circle of a legitimation crisis. When the Continental Congress declared on May 15, 1775 that the authority of the crown should be replaced by new state governments based on the authority of the people, the question immediately arose of the legality of such a decree since there was no longer any precedent for legally claiming the authority of the people. Previously, the law derived its legitimacy from the King and Parliament; with the overthrow of that order, it seemed that legal authority itself was lost. In Philadelphia, a pamphlet called The Alarm soon appeared which raised the question 
of who authorized such an authorization. Warner describes the paradox as follows:

The Assembly was claiming that right, but as The Alarm pointed out, the Assembly derived its legal warrant from the proprietary charter, the authority of which was now void. Were the Assembly to suppress the authority of the Crown and institute the authority of the people, it would be suppressing its own authority and instituting its own authority; thus the Assemblymen might be 'continually making and unmaking themselves at pleasure.' The Assembly, in other words, was not legal enough because it was already legal. (Warner 1991: 99)

One of the solutions Madison drew upon was the practice of creating constitutional conventions which quickly spread after the Declaration. These conventions broke with the vicious circle of finding some legal way to justify the founding law precisely because they were considered to be extra-legal. In Common Sense, Tom Paine describes them as "some intermediary body between the governed and the governors, that is, between the Congress and the people (quoted in Warner 1991: 101)." Madison's goal was to create a national government whose authority would rest on a notion of the people of the United States whose authority would not rest on state governments or the particular constituencies they represented; instead, the American people would constitute "a separate and superior entity" which was "capable of conveying to a national government an authority that would necessarily impinge of the authority of state governments (Morgan 1988: 267)." This notion of the American people would face two directions: It would be a transcendent source of legitimacy yet be embodied in every citizen. Madison's insight was to use the occasion of the Constitutional Convention to create a document which would lay out the legal procedure's for claiming the authority of the people.

By constituting the government, the people's text literally constitutes the people. In the concrete form of these texts, the people decides the conditions of its own embodiment. The text itself becomes not only the supreme law, but the only original embodiment of the people. (Warner 1991: 102)

The printed textuality of the Constitution allows it to emanate from no individual, collectivity, or state in particular, and thus from the people in general. Its circulation mitigated the particularism of local interests, and thereby solved one of the continuing problems of that period: How to balance local interest and the public good by creating a mediation between the two. By building upon the translocal nature of the mediation, it created the ground for a notion of disinterested public virtue. It creates a textualized mediation of what Arendt had called "the worldly in-between space by which men are mutually related" (1963: 175) in which the reading and ratification of the Constitution creates the very "we" that is its opening subject and also its audience, cataphorically instantiating the "we" of the Declaration .

The people serve as the subjectivity that validates the Constitution, but its performativity is different from the appeal to God in the Declaration; it is not an external absolute used to secure the authority of text, but rather it "distributes" its performativity into two separate moments. With its reference to the twelfth year of the Independence of the United States, it links itself back to the performative 
moment of the Declaration, suggesting that the "we" about to be created by the ratification process is continuous with the "we" of the Declaration. At the same time, it makes that "we" the subject/agent of the legal process it is about to constitute. The performative effect of "we the People of the United States...do ordain and establish this Constitution for the United States of America" is to create a "we" that looks like a presupposition for the document's effectiveness, and to create a "we" that the document's ratification will make the source of its power.

Arendt points out the radical breakthrough in the notion of authority that is inscribed in the Constitution by contrasting it with the Roman case which was one of the models for the founding fathers. The Constitution links foundation, augmentation, and conservation; new amendments extend the foundation; even the ratification process for new amendments, involving either a three-fourths vote of the states or of a constitutional convention, recalls the original ratification process. Yet despite the founding fathers' attempts to appropriate the Roman model, in the Roman case, authority "was political, and consisted in giving advice, while in the American republic the function of authority is legal, and it consists in interpretation (Arendt 1963: 200)." The closest thing to an absolute subjectivity mentioned in the Constitution is the creation of a Supreme Court whose justices are appointed for life and therefore not popularly selected, but they are then stripped of any kind of legislative power; theirs is a purely interpretive function, contrasting with the oral, advice giving model of Roman senatorial authority. The mixture of oral and textual models of perfomativity are at the heart of the authority and legitimacy of the whole American constitutional process. As Arendt points out, the word "constitution" has two meanings: The first refers to process, or constituting act whereby a people constitutes itself into a body politic, and the second is the written constitution that results from this act. Arendt brilliantly describes how these two aspects are combined in the "undiscriminating and blind worship" of the Constitution by the people of the United States.

...we may be able to see how ambiguous this worship has always been in that its object was at least as much the act of constituting as it was the written document itself. In view of the strange fact that constitution-worship in America has survived more than a hundred years of minute scrutiny and violent critical debunking of the document as well as of all the 'truths' which to the founders carried self-evidence, one is tempted to conclude that the remembrance of the event itself- a people deliberately founding a new body politic - has continued to shroud the actual outcome of this act, the document itself, in an atmosphere of reverent awe which shielded both event and document against the onslaught of time and changed circumstances. And one may be tempted even to predict that the authority of the republic will be safe and intact as long as the act itself, the beginning as such, is remembered whenever constitutional questions in the narrower sense of the word come into play. (Arendt 1963: 204)

\subsection{Declaring independence and constituting a people}

The contrast between oral and textual forms of performativity are inscribed in the differences between the Declaration of Independence and the Constitution. Although the Constitution relies on the Declaration as "the sole source of authority from which the Constitution, not as an act of constituting government, but as law of the 
land, derives its own legitimacy" (Arendt 1963: 195), it differs remarkably in its form and content. The Constitution makes no overt references to God, or laws of Nature or reason. The preamble opens with the subject performatively created in the Declaration, attributes to it a means-end intentionality ("in Order to form a more perfect Union...."), and then performatively asserts "we...do ordain and establish this Constitution for the United States of America." Article I section I makes a reference to the textual nature of the Constitution:, referring self-reflexively to "All legislative powers herein granted", and then follows a series of articles mostly written in the future tense. It concludes with a statement about the document having been "done" by the "States present" in the twelfth year of the independence of the United States. Whereas in the Declaration, the performativity creates both the subject and the declared independence, in the Constitution there is no subject to be created, only the performative of creating the Constitution. The signatures have no performative effect, in sharp contrast to the Declaration. As Warner puts it,

\begin{abstract}
whereas the climactic moment for the Declaration of Independence was the signing, for the Constitution the climactic moment was the maneuver [i.e, Franklin's motion for unanimous agreement] that deprived signing of personal meaning. For the same reason, whereas the signed copy of the Declaration continues to be a national fetish, from which printed copies can only be derived imitations, the Constitution found its ideal form in every printed copy, beginning, though not specially, with its initial publication, in the place of the weekly news copy of the Pennsylvania Packet. (Warner 1991: 107-108)
\end{abstract}

The audience of the Constitution was the potential citizenry and the state legislatures that would have to ratify it. The "we" therefore has a peculiar inclusive quality. Each addressee/reader is, via the ratification process, potentially a member of this "we", which also includes all other collectivities made up of citizens, including those in the future. It thus forms the "we-ness" at the heart of Anderson's notion of an imagined community of potentially non-present consociates moving through time, giving it an agentive and coordinating force derived from the printed mediation of the document itself. The presupposing and creative dimensions of the performative moment of the Constitution are, in effect, distributed between its cataphoric reference to the Declaration's "we" which then appears as its founding presupposition, and the future ratification and in some sense, perpetual reratification by the people. The outside subjectivity invoked by the declarative speech act of the Declaration is transformed into that of the constitutional legal process itself.

In contrast, the Declaration of Independence was designed to be read aloud. It follows a speech act model of performativity which it secures within a constative order established by God; God also supplies the felicity conditions for its performative effectiveness. It is directed towards fellow colonists, especially those who are wavering, foreign governments whose political recognition the Congress sought, and England. To the colonists, the "we" has the effect of an invited inclusive: You are invited to join us. To others, it has an exclusive quality, indicating that a new subject (a speaking/signing "we" and others -"we" and "they") seeks the addressee's recognition as a sovereign "we" in their own right. At the same time, it seeks to secure such a recognition through a "we" that it does not refer to, that of all the people who share the recognition of God's truths and therefore the justness of the revolutionaries' cause. 
The structure of the document moves from general to performative. The opening sentence is a long general statement in the nomic present tense about the "course of human events". It then locates a specific situation under the "Laws of Nature and Nature's God" in which it becomes necessary for one people to dissolve the political bands that have connected them with one another, makes reference to the opinions of mankind, and then states that those who seek independence should declare the reasons which "impel them to the separation."

In the second sentence, a "we" appears which holds "these truths to be selfevident." It thereby combines the creative self-referentiality of "we" with a stative verb, "hold". The shift from the nomic level of the first sentence to a present reference ("we hold" is ambiguous between a nomic or true present reading) is signaled by the two indexicals "we" and "these" whose reference point is the moment of speaking. The "we" as subject agent selects from among certain truths, "these" self-evident truths which turn out not be the truths of mathematics which were considered to be the paradigm cases of self evidence, but rather truths about human society. The reference to "we" hints at a form of authority which will be secured not by appeal to some absolute, but by mutual agreement. The next several sentences assert how governments are created to embody these truths, and then proceeds to list the King's violation of them. Because of these violations, "we, the representatives of the United States of America" seek the acknowledgment of the justness of our intentions by God (otherwise the performative act would be null and void), and "do ...solemnly publish and declare, that these United States are, and of Right ought to be Free and Independent states." The effect of this declaration is to make the representatives "mutually pledge to each other our Lives, our Fortunes and our sacred Honor", followed by their signatures.

In his reading of the Declaration, Derrida argued that the appeal to truth or a constative moment, always interacts with the performative to create the legitimate referent of the "we" or performing subjectivity. Every performative moment, if it is to be a founding moment, must invoke both: "This obscurity, this undecideability between, let's say a performative structure and a constative structure, is required to produce the sought-after effect (Derrida 1986: 9)." Although he focuses on the intertwining of performative and constative in the signing of the Declaration, their pairing extends throughout the document.

In the Declaration the referent of the initial "we hold" is not disambiguated until the document's performative conclusion. Jefferson drafted the document which was then modified by the representatives of "the United States of America" who are acting "in the Name and by Authority of the good People of these Colonies". The performative is signaled by the choice of the metalinguistic verbs "publish", "declare", and "pledge", the unmarked present tense and aspect, and a "we" that subsumes the individual "I's" that sign; but this "we" is not just a collocation of assembled representatives, but are also representatives of the United States of America. They sign, but their signatures and the felicity of their act is guaranteed by the "rectitude" of their intentions which are vouchsafed by the "Supreme Judge of the World". The rectitude of intentions is one of the felicity conditions for their performative act, and it links the self-evident truths to their real historical understanding as an excuse (another performative) or justification for what will happen. God moves from the level of the transcendent ground of self-evidence, to the judge of intentionality. The link between the eternal truths, the requisite intentions, and the specific act of 
declaring independence is secured by God who guarantees the continuity of one moment to another. The linkage is made explicit in the subordinate clause that these United Colonies are and of right ought to be free and independent states in which the ought actually prepares for the is because of England's violation of the self-evident oughts already announced. The double structure of this oughtness secures both a transcendental ground and a future for the founding performative event. It allows the founding event to be inserted into a chain of oughts, and God becomes the proper name or counter signatory of the people's performative. This performative is secured by the good intentions of the signers, and brings into being that which they purport to represent: The people of the United States of America.

The linguistic structuring of the Declaration also points to the performative moment of speaking and signing. Unlike the Constitution which is written mostly in the future tense, the Declaration opens in the nomic present tense, then moves to the indexical anchoring of "we hold". The list of complaints is written not in the simple past tense, but the present perfect which signals the continuing relevance of the past state of affairs for some reference point. That reference point is established as the present by the performative conclusion of the Declaration; the ongoing relevance of these justifications and the "rectitude" of their present intentions are felicity conditions for the effectiveness of their performative declaration. The spoken performativity of the conclusion is even more dramatic in Jefferson's draft version which reads "we...reject and renounce all allegiance and subjection to the kings of Great Britain...we utterly dissolve all political connections...and finally we do assert and declare these colonies to be free and independent...."

Parallel to the temporal structure from timeless situations to the moment of performative declaration, there is a change in the role of the agency of the "we". In the first sentence, there is only God as an agent. In the second, a "we" is asserted which grasps certain truths, each of which is listed within a complement clause introduced by "that", i.e., "that all men are created equal....") each of which is in a nomic present tense. In the list of provocations, the King is the active agent, and the "we" an object of his unreasonable actions. The "we" that publishes and declares independence still appeals to God to judge the rectitude of their intentions, but the final "we" that mutually pledges creates its performativity unassisted; their "firm reliance" on "divine Providence" is for their own protection, not to guarantee the effectiveness of their pledge to each other.

Despite being a written and then printed text, the Declaration's rhetorical structure indicates that it was meant to be read aloud. Jefferson's still-surviving rough draft of the Declaration is marked with diacritical accents, and the proof copy of John Dunlop's official broadside printing of the Declaration contains inexplicable quotation marks in the opening two paragraphs which are probably the printer's misinterpretations of Jefferson's reading marks (Fliegelmann 1993). All over the colonies, there were public readings of the Declaration designed to overcome the separation of the people into particular classes and occupations.

At the time of the Declaration, rhetoric and oratory were also undergoing a revolution. There was a search for "a natural spoken language that would be a corollary to natural law, a language that would permit universal recognition and understanding (Fliegelmann 1993: 2)." The move to "plainspeak" cut rhetoric from its aristocratic origins as a sign of breeding and proper class behavior, and signaled the public exploration of a private subjectivity in which one's thoughts and feelings 
became self-evident in public. As Jefferson himself put it, oratory had three styles: "The elevated," appropriate for orators and poets, "the middling, appropriate for historians," and "the familiar". The last of these would be suitable for "epistolary and comic writers" (quoted in Fliegelmann 1993: 27) whose works were the popular rage and in which the narrators would address their readers as if they were equals in a frank conversation. The inward turn that Habermas and Taylor describe receives its articulation in novels which create an imagined community of bourgeois readers exploring values of everyday life that would sustain their common social world.

In a post-Lockean milieu that believed the self to be the sum total of its experiences and reflections upon those experiences, reading would become not a substitute for experience but a primary emotional experience itself, a way of understanding and making one's self. (Fliegelmann 1993: 58)

As Fliegelmann has pointed out, this revolution affected all forms of public expression in the Republican era, including art, theater, and music. These forces are all part of the milieu in which Jefferson drafts the Declaration. Jefferson combines the rhetorical models developing in literature with the philosophical models of subjectivity developed by British philosophers. He draws directly upon Locke's Two Treatises for Government in which Locke asserts that "a people" can rise up in revolution if there is "a long train of Abuses, Prevarications, and Artifices" to make his claim in the Declaration that "under absolute despotism" people have the right and duty "to throw off such a government "(see Gustafson 1994: 199 for a fuller discussion). From the assertion of the self-evident truth that governments which deny that men are created equal and have inalienable rights may be overthrown, and the minor premise that Great Britain was such a government, it naturally and inevitably followed that the colonies should be independent. The conviction of the conclusion lay not only in its syllogistic quality, but also in its accordance with the rhetorical principles of the time in which self-evident arguments lead to an intuitive consent by creating a feeling of immediate clarity that reached straight to the heart as well as the head (Fliegelman 1993: 51). The written Declaration speaks with the force of an immediate performative.

\section{Conclusion}

The performativity of the Declaration builds upon an inward, self-reflexive turn which begins in Western philosophy with Descartes and is reworked into the "punctual" self of Locke that Jefferson and the founding fathers drew upon (Taylor 1989). The Declaration aspires to the self-grounded performativity of the cogito, only it is not a solitary thinker which is created, but a people. When we declare that we are independent, we are free and independent. Descartes' model of an indubitable proposition was the complement clause of "I think that I am" because the very act of thinking or saying it made true the subject whose existence the statement asserted. The Declaration aspires to the performativity of cogito, but it has to create both the acting subject, and the state of affairs announced in the complement clause ("we... formally publish and declare that..."). The felicity conditions it has to fulfill are thus of two sorts: that of the subject which is secured through the relays 
between "we", the signatures, and the representatives, and that of the "is and ought" which is secured by God.

The Declaration of Independence is structured to make its conclusion performatively effective. Unlike the complement clause of Descartes' "I think that I am" which is made true by it being thought, no first person declaration by itself can bring about "that these United Colonies are, and of Right ought to be Free and Independent States". While it may be true that in the right circumstances, an assertion or reading aloud of the concluding sentences of the Declaration might indeed be the making of a declaration and a pledge, nothing would guarantee the truth of the complement clause. In a stroke of rhetorical genius, the Declaration sets up in the preceding paragraphs the conditions that must be true if the performative conclusion is to have effect and secure the proper uptake. God's subjectivity and agency is thus invoked as the guarantor of the constative truths that will make the conclusion performative.

The uniqueness of the expanded version of Descartes' cogito, especially in its dico variant ("I say that I am, therefore I am"), is that its assertion is not only performative, but it creates the presupposition needed to make the complement clause true. The assertion "I say that $\mathrm{I} \mathrm{am}^{\mathrm{m}}$ is performatively true whenever I say it; its assertion creates the $I$ which makes the proposition expressed in the complement clause, that I am, true. Since all the illocutionary verbs are hyponyms of the verb to say, embedded in every performative act of promising, declaring, or "formally publishing" is a tacit reference to the performative act of speaking. The difference between speaking and other metalinguistic acts is specified by the differences in their felicity conditions, with saying having minimal ones as, say, compared to promising or excusing. It is this gap between the felicity conditions for the performativity of speaking and the performativity of declaring independence that God's intentions secure in the Declaration. The performativity of the "we publish and declare" lies in the creation of the subject and the performativity of the two metalinguistic verbs. But unlike Descartes' cogito where an act of the thinking subject creates the subject of the propositional complement and therefore guarantees its truth, the mere act of declaring independence cannot secure independence because that requires uptake, i.e., the recognition of the validity of the claim by others. The grounds for this validity claim are provided in the paragraphs preceding the Declaration's conclusion which are written under the eyes of God as witness and guarantor. The act of declaring is placed in a transcendent order that is meant to guarantee its effectiveness. If the appropriate "others" agree with

the argument and then accept the performative creation of the "we" and its declaration of independence, then the complement clause of the performative becomes true, and the colonies become a free and independent state.

There is a subtle creative ambiguity in the chain of we's that connect the Declaration and the Constitution. The referent of the first appearance of the we in the Declaration is not disambiguated until the end of the document. Does the initial we refer only to the signers, or also what they purport to represent, the peoples and people of the colonies? But if the document is to declare and create the fact of independence, then that does not occur until the end of the Declaration, so the referent of the initial we is not created until the end. Yet the performative "we do...formally publish and declare" also appeals to a Cartesian certainty, namely that 
any use of we creates itself as the topic/subject of its own assertion, so at least some subset of the referent of we is created whether the uptake is successful or not. The effect of the reference to God is to place that which is created by the act of formally publishing and declaring, i.e., the declaration by the subject we, as the object of God's divine will which will make what ought to be into what is. God will transform this ambiguous we into thewe of a free and independent nation. The initial performative we which is merely a discourse subject with ambiguous reference, is objectified by God into a we that can stand for a united people which can then be retroactively read back into the first we of "we hold these truths....". The people are created by God's taking that which is created by a social speech act performative and transforming it into a subject/agent in it own right. The subject we of the Constitution's opening performative "captures" the we of the Declaration and embeds it in a text it creates and opens up to an interpretive process which it specifies and inaugurates.

The Constitution thus ushers in a new model of legal and textualized performativity. Whereas the Declaration was criticized as too effective in trying to "captivate the people" (Fliegelmann 1993: 187) with its rhetorical polish, the Constitution was often criticized for its vagueness, abstractness, and ambiguity. A delegate to the Massachusetts convention complained:

I think a frame of government on which all laws are founded, should be simple and explicit, that the most illiterate may understand it; whereas this appears to me so obscure and ambiguous, that the most capacious mind cannot fully comprehend it. (quoted in Gustafson 1992: 278)

Although some of the worries about the meaning of the Constitution would be addressed in the Bill of Rights, much of the anti-Federalist sentiment was fueled by the fear that an aristocratic elite, hiding behind an ambiguous document which required constant reinterpretation, might use the word of law to violate the freedom and liberty of others. They were complaining about the shift from a model of politics in which textual interpretation would replace the populist models of the direct expressivity and sociability of face-to-face communication.

If the Declaration of Independence aspired to the performativity of Descartes' cogito as a founding moment when a new national history would begin, the Constitution embeds that performativity in a textualized iterability it creates. The Constitution changes the punctual quality of the Declarations face-to-face model of performativity with a text mediated, "durative" performativity which "writes in" the conditions for its own uptake. In addition to its "capturing" of the we of the Declaration, it writes the future of its own interpretation into the document in the form of the Supreme Court, and it specifies the conditions of its augmentation through the amendment process. The Constitution creates the institutionalized space of authority into which it inserts itself and its future interpretations, and in so doing, signals a recognition of the intentionalist fallacy. The document is so constructed, from its opening words to the signatures indicating unanimous consent and the establishment of the Supreme Court, to make the intentions of its drafters irrelevant for its interpretation. The founding fathers created the first antifoundationalist founding document. 


\section{References}

Anderson, Benedict (1983) Imagined communities. London: Verso.

Arendt, Hannah (1963) On revolution. London: Penguin Books.

Austin, John (1962) How to do things with words. Cambridge: Harvard University Press.

Benveniste, Emile (1971) Problems in general linguistics. Coral Gables: University of Miami Press.

Derrida, Jacques (1986) Declarations of independence. trans. T. Keenan and T. Pepper. New Political Science 15 (summer 1986).

Fliegelmann, Jay (1993) Declaring independence. Palo Alto, California: Stanford University Press.

Gustafson, Thomas (1992) Representative words. Cambridge: Cambridge University Press.

Habermas, Jurgen (1989) The structural transformation of the public sphere. trans. T. Burger and F. Lawrence. Cambridge: M.I.T. Press.

Honig, B. (1991) Declarations of independence: Arendt and Derrida on the problem of founding a republic. In American Political Science Review, vol. 85, no. 1, March. p 98-113.

Morgan, Edmund (1988) Inventing the people. New York: W.W. Norton Co.

Taylor, Charles (1989) Sources of the self. Cambridge: Harvard University Press.

Taylor, Charles (1994) The Politics of recognition. In Multiculturalism. Amy Gutmann, ed. Princeton: Princeton University Press.

Warner, Michael (1991) Letters of the republic. Cambridge: Harvard University Press.

Wood, Gordon (1969) The creation of the American republic 1776-1787. New York, Norton. 